\title{
Development of Internal Quality Assurance Equal Education
}

\author{
Jamaris \\ Non formal Education Departement \\ Universitas Negeri Padang \\ Padang, Indonesia \\ jamaris_jamna@yahoo.co.id
}

\begin{abstract}
This study aims to find and develop an internal quality assurance system of equality education in Padang city using a quantitative-qualitative combination approach in three years of budgeting. This approach begins with a quantitative approach in identifying the dominant variable determining the internal quality assurance development system. Furthermore, qualitative approach to deepening and development until found a model of internal quality assurance of equal education. This first budget year study was conducted at five Community Learning Activities Centers as a unit of equivalency education in Padang. Data sources consist of managers, learners, educators, and documentation. The results showed that the internal quality assurance system implemented by the equivalency education organizer in Padang City uses a loose-control system. That is, internal quality control is determined by each manager tailored to the will of learners. Managers prioritize the availability and willingness of participants to follow learning either face to face or independent learning activities. Quality assurance of learning, entirely submitted to the awareness of learners.
\end{abstract}

Keywords: graduates, equality education, internal quality assurance, organizing unit, control-release

\section{INTRODUCTION}

Education does not only happen in school (formal education), but also performed anywhere and anytime. Advances in technology and information make education unlimited by space and time, its implementation can be flexible. If prioritizing the education of schooling (formal education), will limit and slow the inheritance of science and technology in the next generation (1). Indonesia has an area of 1,905 million $\mathrm{km} 2$ (2) and 17,508 islands (3). This condition becomes one of the factors of difficulty to accelerate the quality of education of the population. Uneven distribution of the population and difficult to reach areas with educational facilities and infrastructure, Indonesia must make alternative education as an effort of equitable education for all its people (Kohler, Behrman, \& Arianto, 2015).

Flexible education that is able to adjust to the needs of the age and situation and condition of society, is the substance of education outside school. Various educational needs of the community can be met by out-ofschool education, both in urban and rural situations. Outof-school education can meet the needs of the underprivileged to the rich, from early childhood to the elderly. It can also meet the needs of skilled job education as well as to improve work skills on an ongoing basis. From practical functional knowledge to academic knowledge, and so on (Affeldt, Tolppanen, Aksela, \& Eilks, 2017).

Outside school education consists of two channels, namely non-formal education and informal education. These two pathways can be accomplished simultaneously, or complement each other.Non-formal education channel, takes place in the family, society, and education through mass media, social media or information spread anywhere in order to change the attitude, behavior, knowledge, and skills of learners. Non-formal pathway education, such as skills education, training, courses, equivalence education, and other structured education. NFE is used to support the universalisation of primary education (UPE) and literacy programs (Jumani \& Bibi, 2011).

Equality education is one type or unit / program of education equivalent or equal to the level of schooling education in primary and secondary education consisting of package $\mathrm{A}$, package $\mathrm{B}$, and packet $\mathrm{C}$. These three packages represent an academic education path that is equivalent to elementary, junior and senior high schools. The specificity of equality education lies in functional skills as a complementary base of academic knowledge, and the implementation process is not the same as the school system. Implementation of the process of equality education, more emphasis on the control of competencies called the credit units of competence (SKK).

The credit unit of competency prioritizes the competence control by learners. The implementation process does not depend on the time or place of learning or learning. A learner can vary the process in fulfilling the competencies desired by the program or curriculum structure. The age of the learner is not the primary basis for a person to follow an equivalence education. However, it is preferred for community members who are in their teens or school age. The program is aimed at people who choose non-formal education channels as an effort to increase equity and increase compulsory basic and secondary education.

Equality education has long been taking place in this republic. Previously there were several types or educational programs such as education, literacy education, illiteracy education, functional literacy education, and other forms of educational programs similar. Structured equality education has a system with legal rules occurring since the Minister of National Education Regulation on process standards, management standards, graduate competency standards, content standards and equivalence education assessment standards 
around 2007. NFE is used to support the universalisation of primary education (UPE) and literacy programs (Schmidt, Cogan, \& Curtis, 2011).

Some of the phenomena found in the implementation of equality education, among others, most organizers do not have, understand and implement the national standards of equality education. The organizational format mostly refers to the educational system of schooling, the more dominant educator comes from the teacher of school education whose learning uses the formal education approach. In addition, the implementation of UNPK still some deviations from standard operational procedures, most of the students have not maximally followed the educational process contained in the standard. Some learners flocked to register at the time of implementation of UNPK. Supervision of managers or organizers has not been fully controlling the quality, but rather oriented to the expansion of access, the responsible program at the district and provincial and provincial government levels have not been able or not yet have a good system in the implementation of quality assurance.

The national standard of equality education should be a reference for managers and organizers in undertaking internal quality assurance of their institutions (Zhang, 2016). This is the demand of the community, so that the graduates are easily accepted to continue on the next level of education both in non-formal education and in schooling education. People need quality education, this can be achieved if the implementation of equality education has a standardized quality assurance system and a commitment in implementing it. So that some people's doubt about the credibility and quality of equality education graduates can be eliminated (Schmidt et al., 2011).

The quality assurance system for equality education is not only an appeal, but a demand that has to be implemented (Singh, 2014). A very effective quality assurance, if done internally by organizers and learners of equality education programs. The problem is, how is the implementation of internal quality assurance implemented by the providers of equality education in Padang city area?

The city of Padang as the capital of West Sumatera Province, in 2015 has 891 students of Equivalency Education Program of Package A, Package B, and Package C. Group of Equivalent Education Learning which is built by two Learning Activity Center (SKB) located in Kecamatan Padang East and Kecamatan Lubuk Kilangan. The study group numbered 27 groups spread over several kelurahans, and in Penitentiary. Every year students follow UNPK with a good graduation rate (average above $70 \%$ ).

The ever-evolving and dynamic urban conditions make it possible for equality education providers to improve their institutions to ensure quality assurance. The facilities and infrastructure available as urban areas allow for continuous quality improvement. But the existence of society that has lead to individual life, making the existence of the institution is less of a special attention by the community. Thus, the implementation of the equivalency education program is still considered to be the needs of the organizers and the government. In terms of equality education is an effort to increase the individual in facing the development of the necessities of life.

Quality assurance efforts have been done by the Education Office of Padang City, both on the management, implementation of learning and implementation of UNPK (Haseenav, College, \& Vemabllur, 2015). Efforts include providing facilities and infrastructure, operational costs, educational incentives, regular supervision through staff, facilitating by supervising the implementation, coordinating with SKB Pembina, in collaboration with community and nongovernmental organizations, and other efforts. Apparently this business has not shown effective and efficient results. This is evident from the existence of study groups that are increasingly reduced the number of students, and finally closed. Dependency on government funding is very high, when funding is available, learning activities take place, but will be discontinued if funding is not available, especially in Package A and Package B. This event has long been going on, and some even say, "Red plate" (owned by the government), although the organizer is a Community Learning Activity Center (PKBM) established by the community. In line with that, the problem of this research is more focused on the internal quality assurance system of equality education.

Many systems can be applied to implement internal quality assurance of equality education, such as integrated system, partial system, coordination system, empowerment system, awareness system, sustainable quality system, and system of stages. Of the several systems, of course nothing is effective and efficient hundred percent, meaning there is no perfect system. But to build a better system would require minimal risk of weakness. Accordingly, this study limits the problem on the development of the internal quality assurance system of equal education by the organizers together with educators, learners in Padang City.

The purpose of this study was to find an internal quality assurance system for equivalency education. Specifically this study aims to find:

- The internal and internal quality internal quality assurance system includes aspects of planning, management, learning, assessment, supervision and reporting exercises conducted during the first year of the budget.

- The development of an internal quality assurance system for equality education includes aspects of planning, management, learning, assessment, supervision and reporting exercised in the second year of the budget.

- The implementation of the results of the development of the internal quality assurance system of equality education includes aspects of planning, management, learning, assessment, supervision and reporting exercises conducted in the third year of the budget.

\section{METHOD}

This study used a quantitative-qualitative combination approach in three years of budgeting. This approach begins with a quantitative approach in 
identifying the dominant variable determining the development of an internal quality assurance system for equivalency education. Furthermore, qualitative approach in the form of focus group discussion for deepening and development. The pattern is not in the form of stages, when carried out data collection through questionnaires, in line with it also done deepening of some aspects, especially on the problems and solutions that should be done. Finally found a model of internal quality assurance system of practical equality education.

This first year budget research was conducted at five Community Learning Activities Centers as a unit of equal education providers in the city of Padang. Programs that are the subject of the study include package $\mathrm{A}$, Package B, and Package C. The data source consists of managers, learners, educators, and documentation. The deepening of data collection is also done through unstructured interviews on the respondents randomly based on findings and conditions in the field. This is discussed to reveal the problems and needs of internal quality assurance of equivalence education. This data is reduced to complement the results of the data obtained from the questionnaire. A qualitative approach, after finding the initial concept through focused discussions with relevant stakeholders. Distance between the learning groups is not too far away and is easily accessible to the institution of equal education providers.

In order to obtain preliminary data on quantitative descriptions to disclose information from variable indicators, the study population is the whole person directly involved as an equal education provider located in the Padang City area, still actively involved in activities over the past 3 years. They consist of the responsible institutions, program managers and activities, educators and educational participants of equality. The research sample used purposive classified random sampling technique, with the reason that each group represented significantly from required data requirement. To determine the number of samples, a simple simple random sample was taken $65 \%$ of the population.

The collected data is tabulated, and the trend is seen by using the percentage shown in graphical form. To find the contribution of each independent variable with dependent variable by using product moment analysis technique. In finding the contribution of all independent variables simultaneously, then used multiple regression analysis technique. Data obtained from focus group discussions were analyzed using SWOT analysis, both in finding the initial system, as well as for the development of the internal quality assurance system of equivalence education recommended as the findings of this study.

\section{RESULT AND DISCUSSION}

The results of the first year study found conceptually that the internal and internal quality assurance system of equality education that is already underway in Padang City uses a loose-control system. That is, internal quality control is determined by each manager tailored to the will of learners. The planning of institutions or units implementing equivalency education adjusts to the availability of budgets provided by the education office through proposing proposals and necessary data. Managers prioritize the availability and willingness of participants to follow learning either face to face or independent learning activities. Quality assurance of learning, entirely submitted to the awareness of learners. Supervision is emphasized on the availability of supporting documents in taking the national equivalence education exam. Reporting tailored to the needs of the Office of education that provides equivalent equity education funding assistance delivered at the time of examination.

Quantitatively, the result shows that $77 \%$ of planning arrangements adjust to the needs of the education office that provide educational operational support. Implementation of management activities was found to be $76 \%$ adjusting to the situation and conditions of educators, learners, the availability of facilities and infrastructure, and supervision of visits by inspectors. The implementation of $84 \%$ learning is determined by the willingness of learners to learn with reference to the need to take the national equivalence education exam. Implementation of supervision by managers shows as much as $74 \%$ adjusted desire and willingness of managers do it. $65 \%$ of the reporting activities are tailored to the needs of learners and the needs of the education service that provide the funds.

Observing the findings above, that the implementation of the internal quality assurance of equivalence education has not been based on standard operating procedures that refer to the national standard of equality education. In terms of good education should be done with a quality process, standardized and consistent in its implementation. Quality cannot be obtained, without any effort to achieve it. Ways can be obtained to get a quality education, among others, by improving strategies, approaches, objectives, methods, techniques, program improvement, supervision, and systems, and others. That is, the quality assurance should be done as a whole, in order to obtain the maximum results from graduates of equality education (Benavot, 2011).

Quality assurance of education can involve many parties, both external and internal (Almadani, Reid, \& Rodrigues, 2011). Quality is an interrelated system, ranging from Intsrumental input, environmental input, process, out-put, and out-come. The involvement of external parties from many studies shows less effectiveness. The dependence on quality assurance from external parties is more determined by the willingness of the parties and the sanctions and rewards given. If that does not work well, then quality assurance efforts may be stopped by the education institution or provider. Quality assurance by external parties is usually dominantly determined by a sense of responsibility and financing that supports it as evidenced by the findings of this study.

Efforts to encourage internal parties in quality assurance have proved a very high level of success. There are many advantages, such as awareness and quality culture, more efficient financing, optimization of existing potential, sustainable implementation, multiple awards, and other benefits.

Internal quality assurance, must be built with a synergy or a good system between managers, educators and learners (O'Mahony \& Garavan, 2012). The effect 
that between them occurs is to remind each other that one of the sub-systems does not perform its role well. They feel they have and are responsible for the quality they want together and should be managed as potential human resources. Each performs a role in the quality of processes and outcomes of equality education (Ruechakul, Erawan, \& Siwarom, 2015). Involvement in planning, implementation, supervision in joint policy decisions will find the quality of equality education. The effort to raise the spirit or the culture of quality that becomes a habit, becomes a strategy that needs to be developed. Involvement is a process of empowering the potential of the community through education out of school (Christens, 2012). However, if it is based on the concept or the outcome of thinking alone, it is difficult to obtain the aspect that becomes the fundamental need for the realization of internal quality assurance.

\section{CONCLUSION AND RECOMMENDATION}

The result of research stated that the internal quality assurance system implemented by the equality education organizer in Padang City uses a freelance control system. That is, internal quality control is determined by each manager tailored to the will of learners. Managers prioritize the availability and willingness of learners to follow learning either face to face or independent learning activities. Quality assurance of learning, entirely submitted to the awareness of learners. It is recommended that each educational unit establish and implement consistently the operational standards of internal quality assurance procedures with reference to the national standard of equality education. Furthermore, to do further research to get the model relevant to the needs of each unit in conducting internal quality assurance.

\section{REFERENCES}

[1] Affeldt, F., Tolppanen, S., Aksela, M., \& Eilks, I. (2017). The potential of the non-formal educational sector for supporting chemistry learning and sustainability education for all students - a joint perspective from two cases in Finland and Germany. Chem. Educ. Res. Pract., 18(1), 1325. https://doi.org/10.1039/C6RP00212A
[2] Almadani, K., Reid, N., \& Rodrigues, S. (2011). Quality Assurance: A Pressing problem for Education in the 21st Century. Problem of Education in the 21st Century, 32, 922.

[3] Benavot, A. (2011). Improving the Provision of Quality Education: Perspectives from Textbook Research. Journal of International Cooperation in Education, 14(2), 1-16. https://doi.org/10.15027/34394

[4] Christens, B. D. (2012). Targeting empowerment in community development: A community psychology approach to enhancing local power and well-being. Community Development Journal, 47(4), 538-554. https://doi.org/10.1093/cdj/bss031

[5] Haseenav, A., College, M. E. S. A., \& Vemabllur, P. (2015). Aspects of Quality in Education for the Improvement of Educational Scenario. Journal of Education and Practice, 6(4), 100-106.

[6] Jumani, N. B., \& Bibi, K. (2011). Potential of non-formal basic education in promoting women education in Pakistan. International Journal of Instruction, 4(1).

[7] Kohler, H.-P., Behrman, J. R., \& Arianto, D. (2015). Indonesia Perspectives: Population and Demography. Retrieved from http://www.copenhagenconsensus.com/sites/default/files/in donesia_packet_population.pdf

[8] O'Mahony, K., \& Garavan, T. N. (2012). Implementing a quality management framework in a higher education organisation: A case study. Quality Assurance in Education, 20(2), 184-200. https://doi.org/10.1108/09684881211219767

[9] Ruechakul, P., Erawan, P., \& Siwarom, M. (2015). Empowering Communities in Educational Management: Participatory Action Research. International Education Studies, 8(9), 65-78. https://doi.org/10.5539/ies.v8n9p65

[10] Schmidt, W. H., Cogan, L. S., \& Curtis, C. M. (2011). Equality of educational opportunity: Myth or reality in U.S. Schooling? American Educator, 24(4), 12-19. https://doi.org/10.1146/annurev.soc.14.1.249

[11] Singh, K. (2014). Right to Education and Equality of Educational Opportunities. CICE Hiroshima University, Journal of International Cooperation in Education, 16(2), 5-19. Retrieved from http://home.hiroshimau.ac.jp/cice/wp-content/uploads/2014/10/16-2-1.pdf

[12] Zhang, H. (2016). Educational Equity Research in the Mainland of China: A Historical Perspective. International Education Journal: Comparative Perspectives, 15(4), 133147 